\title{
DEVELOPING DIGITAL TEACHING MATERIALS FOR PROSE FICTION APPRECIATION TO FOSTER LEARNING AND ENGAGEMENT
}

\author{
Siti Cholisotul Hamiah, Endah Tri Priyatni, ${ }^{*}$ Heri Suwignyo \\ (Indonesian Literature and Linguistics, Universitas Negeri Malang)
}

\begin{tabular}{ll}
\hline A R T I C L E I N F O & A B S T R A C T \\
\cline { 2 - 4 } $\begin{array}{ll}\text { Keyword: } & \text { This study is aimed at developing digital teaching materials for Prose Fiction } \\
\text { teaching materials, } & \text { Appreciation course to foster students' learning and engagement. This study employed } \\
\text { digital, } & \text { research and development design summarized in 4D steps: Define, Design, Develop, } \\
\text { engagement } & \text { and Disseminate. The results of validation and product testing show that the teaching } \\
& \text { materials are suitable for the learning and able to foster the students' learning and } \\
& \text { engagement. The notion of engagement is of great importance to be promoted as it } \\
& \text { suggests that the students are active learning subjects. }\end{array}$ \\
\hline
\end{tabular}

What are the defining characteristics of $21^{\text {st }}$-century learners? This question is worth asking for these learners will be those that prospective teachers who are currently attending universities have to deal with, including prospective teachers of Indonesian literature and linguistics. An understanding of the characteristics of 21st-century learners will help the teacher determine the suitable selection of teaching materials, learning strategies, media, and learning evaluation.

The $21^{\text {st }}$-century learners are deemed to be a digital generation. They have grown up with an easy access to technology, thus rendering them more technology literate; they are users of mobile technology by which they can find information anytime and anywhere easily from laptops and smartphones; they are highly adaptable (Jati, 2016). This tendency makes learning tasks focused on what-, when-, and how-type questions no longer fully appropriate for these digital generation learners. As such, the teacher does not serve as the only source of learning activities.

The $21^{\text {st }}$-century learners are good at multitasking generation meaning that they can perform several tasks at the same time. Smartphones are one of the media widely used by learners for multitasking. Learners prefer to multitask while studying in the classroom. However, research findings show that multitasking does not satisfy cognitive needs but emotional needs (Tchernev, 2012).

Withdrawing students from multitasking with their smartphones is not a wise decision based on sound judgment. To approach this problem, it is essential to consider the integration of technology in learning activities. Learning activities must provide opportunities for learners to access learning materials or resources by utilizing their smartphones and the learning material must previously be well designed so that learners are able to solve problems, find solutions, and write/publish their work using their smartphones. This way will create a learning experience that fosters students' learning engagement and simultaneously develops creative-critical thinking skills. Rosen et al. (2012) assert that the learning approach by integrating technology can help improve the learning focus of the respondents.

Integration of technology into classroom learning must function as an intellectual partner in the learning process. Learners do not learn from technology but learn from technology-facilitated thought processes (Jonassen, et al., 2003). Technology must help foster engagement and support thinking skills.

\footnotetext{
${ }^{*}$ Corresponding author.

E-mail addresses: endah.tri.fs@um.ac.id (Endah Tri Priyatni)
}

ISSN : 2597-7385 (Online) - ISLLAC : Journal of Intensive Studies on Language, Literature, Art, and Culture is licensed under Creative Commons Attribution-ShareAlike 4.0 International License (http://creativecommons.org/licenses/BY/4.0/). 
Technology must function as an intellectual tool that enables learners to be able to build meaningful personal interpretations facilitated by technology. To meet the needs of the students in improving their creative thinking skills and simultaneously building their learning engagement, an e-learning website hosted in the e-learning domain of Universitas Negeri Malang is an instance of employment of technology to achieve those goals.

The technology-based teaching materials developed in this study are teaching materials for Prose Fiction Appreciation, a course offered for students of Indonesian Literature and Linguistics program as well as students of Indonesian and Regional Language Teaching program, Faculty of Letters, Universitas Negeri Malang. The teaching materials facilitate the students to (1) download a variety of selected literary texts accessed from various sources, (2) download various tasks of literary appreciation, which facilitate them to think critically-creatively, (3) publish student ideas from the given problem-based tasks, (4) and conduct interactive and collaborative discussions through web-based online media.

The technology-based teaching materials developed in this study are expected to foster students' engagement and creative-critical reading skills. By engagement, it is not intended to merely create fun activities; it, more importantly, includes active learning, the results of which are long-term (not momentary), meaningful and applicable, problem-solving based, and interactive, placing a great emphasis on creativity and readers' participation. Such engagement is promoted through the suitable selection of texts that comply with the needs and interests of the learners; they are actively involved in the problemsolving process and discussion aimed at encouraging the students to voice their ideas in the form of students' work published on the web where the public can provide suggestions, comments, and interaction concerning the students' learning products (Kalantzis, 2015).

Critical thinking skills are also important aspects developed in this technology-based teaching materials for Prose Fiction Appreciation. Critical thinking skills are of great importance to validate, synthesize, communicate, collaborate, and solve any kinds of information massively produced in the digital platforms, the sources of which highly vary and are not necessarily reliable. Therefore, critical thinking skills are essential so that we can survive and even play an active role in the $21^{\text {st }}$ century.

In addition, creative thinking is one's thinking ability that starts from one's sensitivity to the challenging problems being faced (Erwin, 2018; Gay, 2018; Nurchasanah \& Habsari, 2017). Furthermore, there is an element of originality of ideas that arise in a person's mind related to what is identified. The results that arise from creative thinking provide a sense of novelty for the person concerned and are something different from what they usually do. Creative thinking also appears in the form of the ability to find new relationships and to look at things from a different perspective.

Creative thinking can be tracked in four forms, namely, sensitivity, fluency, flexibility, and originality. Regarding these four central elements of creative thinking that operate in one's thought processes, it is deemed necessary to have a further action to help the person become more aware of his own thought processes and organize them well. This is so, for the learner will not lose momentum during the learning process and the good ideas that emerge from the learning will lapse. This orderly and detailed arrangement opens the opportunity for the learners to be able to repeat or read at any time and review what they have produced.

In light of the background of the study, the problem of this study is formulated as follows: what kinds of technology-based teaching materials for Prose Fiction Appreciation can be used to foster student teachers' learning and engagement in Indonesian Literature and Linguistics program?

\section{METHOD}

This study employed to research and development design to develop products in the form of technology-based teaching materials for Prose Fiction Appreciation (henceforth, PFA). This research design employed a 4D model: Define, Design, Develop, and Disseminate (Thiagarajan, 1974). The four stages of developing the 4D model are outlined in the following parts.

The first stage is to Define. The main objective of this first stage was to establish the instructional requirements needed to develop the product. This first stage was analytical in nature, employed to determine the instructional objectives and constraints faced in the product development. The first stage contained the following five steps: (1) analyzing the fundamental problems faced by prospective product users to achieve the expected competencies (front-end analysis) (2) analyzing the characteristics of learners who will use the product (competency, background experience, general attitude towards the topic) (learner 
analysis), (3) analyzing tasks and identifying key skills and sub-skills needed to achieve expected competencies (task analysis), (4) analyzing essential concepts that will be taught (concept analysis), and (5) developing specific learning goals based on the results of the analysis (specifying instructional objectives).

The second stage is the Design. The main objective of the second phase was to develop a prototype of digital technology-based teaching materials for PFA. This stage started after specific instructional objectives had been set. At this stage, the media and the format of teaching materials were selected as the initial version of the product. There were four steps carried out in the second stage: (1) compiling the testreference criteria that are converted in the form of teaching material frameworks, (2) selecting the media, (3) selecting ways to present the teaching materials, and (4) preparing the initial design.

The third stage is Develop. The purpose of this third stage was to modify the prototype that had been developed previously. The developed prototype was shown to the experts for feedback and tested to potential product users. The feedback gained from the expert team and the results of the trial were used to modify the product. In brief, there were two main steps carried out at the development stage. First, it dealt with a test by experts, techniques to get suggestions for improving teaching materials developed. A number of experts were asked to evaluate the teaching products for PFA that had been developed by using certain criteria. Based on the assessment of the expert team, the products were adjusted to make them more effective, useful, and of high quality. Second, it dealt with testing the products to the potential product users. The modified products were tested to prospective product users to elicit their responses, reactions, and comments regarding the products. Based on the responses gained from the potential product users, the product was revised and retried out until the product was consistent and effective.

The fourth stage is Disseminate. The development of teaching materials was deemed to be finished when the results of the tests showed consistent results and the experts provided positive comments concerning the quality of the product. The product could be disseminated when they had been through product testing by experts and prospective product users. Before being disseminated, the product needed packaging, diffusing and adaptation. The layout, cover, and features included in the product were made and the final product was socialized to the potential product users.

The types of data in this study consisted of two categories, namely, qualitative and quantitative data. The qualitative data were in the form of responses, suggestions, and comments elicited from experts and students (prospective users of the product). The quantitative data were in the form of scores obtained from the assessment by the experts related to the developed product. The instruments employed to collect the data in the form of product assessment guidelines for qualitative data collection and product review guides for quantitative data collection. The source of the intended data for the product trials was elicited from students of Indonesian Literature and Linguistics program as well as students of Indonesian and Regional Language Teaching program taking the Prose Fiction Appreciation course for the odd semester, 2017.

To analyze the data, the researchers grouped the data based on the domain of research, interpretation, reflection, and data inference. The analysis included the content, form, language, practicality, and attractiveness of the product.

\section{FINDINGS}

The product of this study is in the form of e-learning teaching materials uploaded on the e-learning website of Universitas Negeri Malang. The lecturer in charge of this course can access the website through the um.ac.id-e-learning page and E-Learning UM-Universitas Negeri Malang will appear. After clicking the link, the homepage will read 'Welcome to the online learning page of Universitas Negeri Malang'. On that page, an image of a digital class is displayed. To enter the PFA class, type the name of the course and click 'Go'.

By clicking the course, a page will appear and ask the user to log in. It should be done by using the username and password provided in the ICT Center. The lecturer must also ask for a username and password for all students who take the PFA course so that the students can download and upload their works in the digital class of the course.

The digital teaching materials for PFA course have some features: (1) announcements, (2) semester academic plan (RPS), (3) assignments 1 to 4, (4) assignment submission, and (5) evaluation. In addition, there is also a feature for discussion forum provided for the participants of the PFA course. Each of these features is described in the following sections. 
The announcement feature contains information related to learning activities in the classroom entailing learning groups, the arrangement of class discussions, and materials to be learned. This includes notifications about students who have not collected the resume of the learning materials. Otherwise, the discussion will not run smoothly. By doing so, the students can pose better questions because they have reviewed the concept necessary to actively take part in the discussion. The students are then wellprepared. The announcement feature on the FPA class page is rarely used because the students prefer to use WhatsApp, which is faster, easier, and not complicated.

The Prose Fiction Appreciation course with a code of P MKKU616 is equal to 3 credits. This course belongs to the category of Literary Skills. This means that learning activities must emphasize practical activities to appreciate various works of fiction. Discussion of theoretical aspects, such as the nature of appreciation, prose fiction, and approaches to the appreciation of prose fiction, is presented in the framework of providing practical activities to appreciate a variety of works of fiction. The percentage of theory and practice activities is 40:60. The maximum theoretical activity is $40 \%$ and practical activity is $60 \%$.

The purpose of the PFA course is that the students comprehend the nature and purpose of the appreciation of prose fiction, the variety, and structure of prose fiction, fundamental knowledge to appreciate the variety of Indonesian fiction prose, and apply various approaches and stages to appreciate various works of fiction. This course discusses (1) the nature and purpose of fiction prose appreciation, (2) the variety and structure of Indonesian fiction prose, (3) prose fiction appreciation approach; (4) fundamental knowledge as an appreciator; (5) stages of appreciation, and (6) appreciation of the variety of Indonesian fiction prose. The nature of prose fiction is studied so that the students recognize the difference between prose fiction and narrative works that are not in the category of prose fiction. An understanding of the nature of prose fiction is sharpened by the study of various types of prose fiction, ranging from new prose fictions such as short stories, novels, novels, romance, fantasy stories and also old prose fiction such as fairy tales, fables, and legends. The activity is followed by the practice of analyzing the intrinsic and extrinsic structures of various works of fiction. The discussion of approaches to the appreciation of prose fiction is also carried out and integrated with the appreciation of prose fiction using a particular approach.

In the given task, Feature 4 (reflecting), the students are asked to recapture their learning experience, think about it, and evaluate it. Reflection thinking involves the following three activities: (1) revisiting the previous experience, activities to recall important events in detail, (2) expressing feelings, activities to employ feelings to express things that are liked or disliked, and (3) evaluating the previous experience, activities to re-examine experiences based on existing intentions and knowledge.

In the other feature, results, and discussion, all the works that have been produced and uploaded by students can be seen there. In this feature, the students can see their peers' work and at the same time give comments.

Related to the digital teaching materials for PFA course, the researches have received qualitative input from a team of experts, practitioners, and students. These essential suggestions or comments can be seen in Table 1 below.

Table 1: Feedback from the Validators

\begin{tabular}{|c|c|c|c|}
\hline $\begin{array}{c}\text { Aspects } \\
\text { under } \\
\text { Evaluation }\end{array}$ & $\begin{array}{l}\text { Indicators for } \\
\text { Each Aspect }\end{array}$ & Feedback & Follow-up \\
\hline \multirow[t]{2}{*}{$\begin{array}{l}\text { Semester } \\
\text { Academic } \\
\text { Plan }\end{array}$} & $\begin{array}{l}\text { Providing the } \\
\text { identity of the } \\
\text { course with a } \\
\text { complete and } \\
\text { correct framework }\end{array}$ & $\begin{array}{l}\text { The identity is } \\
\text { complete. Spelling } \\
\text { needs correcting, } \\
\text { e.g. local should be } \\
\text { spelled lokal. }\end{array}$ & $\begin{array}{l}\checkmark \text { Correcting the } \\
\text { misspelled } \\
\text { words. }\end{array}$ \\
\hline & $\begin{array}{l}\text { Providing } \\
\text { graduates' } \\
\text { competency } \\
\text { achievement and } \\
\text { learning outcomes }\end{array}$ & $\begin{array}{l}\text { Learning outcomes } \\
\text { for the course is } \\
\text { not evident. } \\
\text { - Spelling needs } \\
\text { correcting. }\end{array}$ & $\begin{array}{l}\checkmark \text { Including the } \\
\text { learning } \\
\text { outcomes. } \\
\checkmark \text { Correcting the } \\
\text { misspelled }\end{array}$ \\
\hline
\end{tabular}




\begin{tabular}{|c|c|c|c|c|}
\hline & $\begin{array}{l}\text { for the course in } \\
\text { the cognitive, } \\
\text { affective, and } \\
\text { performative } \\
\text { domains with the } \\
\text { correct framework }\end{array}$ & & & words. \\
\hline & $\begin{array}{l}\text { Providing final } \\
\text { competencies and } \\
\text { indicators in } \\
\text { accordance with } \\
\text { the learning stages } \\
\text { to meet the } \\
\text { learning outcomes } \\
\text { with the correct } \\
\text { framework. }\end{array}$ & $\begin{array}{l}\text { Indicators for } \\
\text { elements and } \\
\text { structures of prose } \\
\text { fiction should be } \\
\text { clearer. They are } \\
\text { still vague. }\end{array}$ & $\checkmark$ & $\begin{array}{l}\text { Making the } \\
\text { indicators for } \\
\text { competency } \\
\text { achievement } \\
\text { clearer. }\end{array}$ \\
\hline & $\begin{array}{l}\text { Providing } \\
\text { references in } \\
\text { accordance with } \\
\text { the final outcomes } \\
\text { and indicators } \\
\text { with the correct } \\
\text { framework. }\end{array}$ & $\begin{array}{l}\text { The references } \\
\text { should comply with } \\
\text { the learning } \\
\text { outcomes for the } \\
\text { course. Each } \\
\text { learning outcome } \\
\text { should be in line } \\
\text { with the reference. }\end{array}$ & $\checkmark$ & $\begin{array}{l}\text { Making the } \\
\text { references } \\
\text { comply with the } \\
\text { learning } \\
\text { outcomes for } \\
\text { the course. }\end{array}$ \\
\hline & $\begin{array}{l}\text { Providing various } \\
\text { methods } \\
\text { complying with } \\
\text { the competency } \\
\text { achievement. }\end{array}$ & $\begin{array}{l}\text { - The method is less } \\
\text { varied. }\end{array}$ & $\checkmark$ & $\begin{array}{l}\text { Adding more } \\
\text { various } \\
\text { methods. }\end{array}$ \\
\hline & $\begin{array}{l}\text { Providing } \\
\text { indicators, } \\
\text { assessment } \\
\text { guidelines, and } \\
\text { instruments for } \\
\text { the competency } \\
\text { achievement. }\end{array}$ & $\begin{array}{l}\text { Instances of the } \\
\text { instrument are not } \\
\text { provided. }\end{array}$ & $\checkmark$ & $\begin{array}{l}\text { Providing } \\
\text { instances of the } \\
\text { instruments. }\end{array}$ \\
\hline & $\begin{array}{l}\text { Providing relevant } \\
\text { references } \\
\text { published in the } \\
\text { recent } 5-10 \text { years. }\end{array}$ & $\begin{array}{l}\text { - The references are } \\
\text { not updated. }\end{array}$ & $\checkmark$ & $\begin{array}{l}\text { Updating the } \\
\text { references with } \\
\text { the current } \\
\text { publications } \\
\text { (5-10 years) }\end{array}$ \\
\hline \multirow[t]{2}{*}{ Task 1-4 } & $\begin{array}{l}\text { The tasks are } \\
\text { appropriate to } \\
\text { achieve the } \\
\text { learning } \\
\text { objectives. }\end{array}$ & - Highly appropriate & & \\
\hline & $\begin{array}{l}\text { The tasks are } \\
\text { appropriate to } \\
\text { foster } 21^{\text {st }} \text { skills: } \\
\text { critical, creative, } \\
\text { collaborative, and } \\
\text { communicative. }\end{array}$ & - Highly appropriate. & & \\
\hline $\begin{array}{l}\text { Digital } \\
\text { Technology }\end{array}$ & $\begin{array}{l}\text { The suitability of } \\
\text { the integrated }\end{array}$ & $\begin{array}{l}\text { - The students' } \\
\text { creativity needs }\end{array}$ & $\checkmark$ & $\begin{array}{l}\text { Providing an } \\
\text { additional }\end{array}$ \\
\hline
\end{tabular}




\begin{tabular}{|c|c|c|c|}
\hline & $\begin{array}{l}\text { technology with } \\
\text { the learning } \\
\text { structures to } \\
\text { enhance the } \\
\text { students' critical } \\
\text { thinking and } \\
\text { creative writing. }\end{array}$ & $\begin{array}{l}\text { optimizing by } \\
\text { providing more } \\
\text { writing tasks. } \\
\text { The creative writing } \\
\text { activities need } \\
\text { optimizing. } \\
\text { The ability to give } \\
\text { critical comments is } \\
\text { not really evident. }\end{array}$ & $\begin{array}{l}\text { writing task in } \\
\text { the form of a } \\
\text { reflective essay. } \\
\checkmark \text { Providing } \\
\text { guidelines for } \\
\text { reflective } \\
\text { activities so that } \\
\text { they are focused } \\
\text { on essential } \\
\text { aspects at depth. }\end{array}$ \\
\hline & $\begin{array}{l}\text { The suitability of } \\
\text { the integrated } \\
\text { technology with } \\
\text { the learning } \\
\text { structures to } \\
\text { enhance the } \\
\text { students' ability to } \\
\text { collaborate and } \\
\text { communicate. }\end{array}$ & $\begin{array}{l}\text { Student-to-student } \\
\text { interaction needs } \\
\text { improving. } \\
\text { Discussion among } \\
\text { students can be } \\
\text { facilitated through } \\
\text { reflective activities } \\
\text { related to students' } \\
\text { learning experiences } \\
\text { during the course. }\end{array}$ & $\begin{array}{l}\text { It is compulsory } \\
\text { for each student } \\
\text { to reflect on } \\
\text { their peer's } \\
\text { work. }\end{array}$ \\
\hline Language & $\begin{array}{l}\text { The effectiveness } \\
\text { of the language } \\
\text { used on the } \\
\text { website. }\end{array}$ & $\begin{array}{l}\text { The effectiveness of } \\
\text { language used should } \\
\text { be well considered. The } \\
\text { provided texts should } \\
\text { be free from errors. }\end{array}$ & $\begin{array}{l}\text { Revising the } \\
\text { ineffective language } \\
\text { use, including } \\
\text { misspelled words } \\
\text { and punctuations. }\end{array}$ \\
\hline $\begin{array}{l}\text { The } \\
\text { appearance } \\
\text { of the } \\
\text { website }\end{array}$ & $\begin{array}{l}\text { The suitable } \\
\text { selection of image, } \\
\text { font, layout, and } \\
\text { color. }\end{array}$ & $\begin{array}{l}\text { The appearance of the } \\
\text { e-learning web is less } \\
\text { interesting. }\end{array}$ & $\begin{array}{l}\text { Requesting other } \\
\text { types of the } \\
\text { appearance of the e- } \\
\text { learning web to the } \\
\text { ICT Center. }\end{array}$ \\
\hline
\end{tabular}

Trying out the product to the student is carried out to describe the existence of engagement through initial testing and describe creative-critical reading skills through quantitative testing with the following steps.

\begin{tabular}{|l|l|l|l|l|l|}
\hline Steps & Background & $\begin{array}{l}\text { Number } \\
\text { of } \\
\text { Students }\end{array}$ & $\begin{array}{l}\text { Types of } \\
\text { Data }\end{array}$ & Revision & Meetings \\
\hline $\begin{array}{l}\text { Initial } \\
\text { Testing }\end{array}$ & $\begin{array}{l}\text { The product } \\
\text { is tried out to } \\
\text { a small group } \\
\text { of students } \\
\text { by asking } \\
\text { them to } \\
\text { write } \\
\text { reflective } \\
\text { journals } \\
\text { (Task 4) }\end{array}$ & $\begin{array}{l}10 \\
\text { students }\end{array}$ & $\begin{array}{l}\text { Qualitative: } \\
\text { Responses } \\
\text { of the } \\
\text { students } \\
\text { written in } \\
\text { the } \\
\text { reflective } \\
\text { journals. }\end{array}$ & $\begin{array}{l}\text { Several } \\
\text { aspects from } \\
\text { the developed } \\
\text { teaching } \\
\text { materials. }\end{array}$ & $\begin{array}{l}\text { 4-5 } \\
\text { meetings } \\
\text { (until } \\
\text { consistent } \\
\text { findings } \\
\text { are } \\
\text { present) }\end{array}$ \\
\hline $\begin{array}{l}\text { Quantitative } \\
\text { testing }\end{array}$ & $\begin{array}{l}\text { A small } \\
\text { group of } \\
\text { students } \\
\text { works on }\end{array}$ & $\begin{array}{l}10 \\
\text { students }\end{array}$ & $\begin{array}{l}\text { Data } \\
\text { related to } \\
\text { the } \\
\text { students }\end{array}$ & $\begin{array}{l}\text { Revising some } \\
\text { tasks designed } \\
\text { previously. }\end{array}$ & $\begin{array}{l}\text { 4-5 } \\
\text { meetings } \\
\text { (depending } \\
\text { on how }\end{array}$ \\
\hline
\end{tabular}




\begin{tabular}{|l|l|l|l|l|}
\hline & Task 3 & & $\begin{array}{l}\text { critical- } \\
\text { creative } \\
\text { reading } \\
\text { skills from } \\
\text { writing test. }\end{array}$ & \\
& & & $\begin{array}{l}\text { many } \\
\text { aspects } \\
\text { that need } \\
\text { revising) }\end{array}$ \\
\hline
\end{tabular}

The findings of the study related to engagement seen from reflective journals show that the 10 students as the experimental subjects feel involved cognitively and emotionally in the learning.

The students' involvement cognitively can be seen from their enthusiasm in learning each competency taught in the PFA course. In addition, the students are also emotionally involved in the learning activities. The students express their excitement when they encounter new things during the learning process and also express their boredom when the learning method is less varied.

\section{DISCUSSION}

There are five aspects that are validated from digital teaching materials for the FPA course: (1) Semester Academic Plan (Rencana Pembelajaran Semester/RPS), (2) assignments to be done by students, (3) digital technology, (4) language, and (5) homepage/website layout.

The RPS has an important role in developing the teaching materials because they are developed in accordance with the RPS. The content of the RPS is developed by lecturers or groups of lecturers in their respective field of expertise. Regarding the RPS, there are a number of aspects that must be refined: (1) including learning outcomes of the course (CPMK) that has not been stated in the RPS, (2) aligning the study material with the CPMK, (3) developing indicators of competency achievement more clearly, (4) employing more various methods, (5) adding more instruments, and (6) updating reference books.

Regarding the Tasks 1 to 4 , they are considered appropriate. This means that the tasks that must be completed by students are well designed and able to foster students' learning and engagement. The design of the tasks also enables the students to think critically, creatively, and collaboratively, which help them develop their communicative abilities.

Related to the digital technology, there are a number of aspects that still need optimizing: (1) it is necessary to add more creative writing tasks and (2) provide spaces to reflect on the work of other students through discussion forums in the digital class. Concerning language, it needs correcting due to less precise spelling and ineffective sentences. The last aspect, the layout of the website, is still being tried out because the digital technology used is designed by the ICT team from Universitas Negeri Malang.

The results of the study related to engagement show that $100 \%$ of the students feel involved cognitively and emotionally in the learning process of the PFA course. Engagement has various definitions. Kuh et al. (2009) assert that engagement includes the time and energy invested by students to effect learning. Engagement means there is a sense of responsibility for students to be actively involved in learning. Fredricks et al. (2004) state that engagement is a holistic process because student involvement is not only about correct behavior but also involves cognitive investment and their emotional commitment to learning. Cognitive involvement shows investment in learning concepts and skills in depth as well as the construction of individual and transformative meaning. Moreover, emotional involvement occurs because of a sense of belonging and security.

Solomonides et al. (2012) offer a relational framework to identify several factors that help students understand their learning experiences. Engagement arises when students get a sense of being and transformation in mastering knowledge central in their disciplines.

From the results of the study, it can be concluded that the digital teaching material for PFA course and the learning process have facilitated the lecturers to foster students' learning and engagement. The notion of engagement is important to be promoted among students because of the involvement of the students in learning shows that students are active agents and subject of learning. They play a role as autonomous learners who determine the depth of the material to be studied, which direction and target to be addressed in learning so that they will become lifelong learners; they learn not just to meet the requirements to pass the course. 


\section{CONCLUSIONS}

There are five aspects that have been validated regarding the digital teaching materials for the Fiction Prose Appreciation course: (1) Semester Academic Plan (RPS), (2) assignments to be done by students, (3) digital technology, (4) language, and (5) website layout.

Related to the RPS, there are some aspects that have been refined: (1) including learning outcomes of the course (CPMK), (2) aligning the study material with the CPMK, (3) developing indicators of competency achievement more clearly, (4) employing more various methods, (5) adding more instruments, and (6) updating reference books.

Regarding the Tasks 1 to 4 , they are deemed to be appropriate. This suggests that the tasks tailored for the students are well designed and able to foster students' learning and engagement, facilitating them to think critically, creatively, collaboratively to develop their communicative abilities.

Related to the digital technology, there are a number of aspects that have been optimized: (1) the addition of more creative writing tasks and (2) the provision spaces to reflect on the work of other students through discussion forums in the digital class. Concerning language, it needs correcting due to less precise spelling and ineffective sentences. The last aspect, the layout of the website, is still being tried out because the digital technology used is designed by the ICT team from Universitas Negeri Malang. With this improvement, this e-learning web designed for Fiction Prose Appreciation course is deemed feasible to be implemented.

The results of the study related to engagement demonstrate that $100 \%$ of the students feel involved cognitively and emotionally in the learning process of the PFA course. From the findings, it can be concluded that the digital teaching material for PFA course and the learning process have been able to foster students' learning and engagement.

\section{REFERENCES}

Erwin, E. (2018). LEARNING BASED ON ENVIRONMENT AS STIMULUS TO THINK CRITICAL IN LEARNING THE INDONESIAN LANGUAGE IN THE 3T AREA. ISLLAC: Journal of Intensive Studies on Language, Literature, Art, and Culture, 2(1), 7-13.

Fredricks, J; Blumenfeld, P; \& Paris, A. (2004). School engagement: Potential of the concept, state of the evidence. Review of Educational Research, 74(1), 59-109.

Gay, M. (2018). WRITING LEARNING STRATEGY AND READING POETRY BASED FOR TRADITIONAL GAMES CRITICAL THINKING PROCESS. ISLLAC : Journal of Intensive Studies on Language, Literature, Art, and Culture, 2(1), 62-70.

Jati, G. (2016). Teknologi, Literasi, dan Pembelajaran Bahasa untuk Generasi Z.Makalah, disampaikan dalam Kuliah Tamu Prodi S2 Keguruan Bahasa, tanggal 1 September 2016.

Jonassen, H.; Howland, J.; Moore, J.; Marra, R.M. (2003). Learning to Solve Problems with Technology.New Jersey, Columbus, Ohio: Merrill Prentice Hall.

Kalantzis, M dan Cope, B. (2015). Literacies. Cambridge: Cambridge University Press.

Kuh, G. (2009). The national survey of student engagement: Conceptual and empirical foundations. New Directions for Institutional Research, 141, 5-20. Doi:10.1002/ir.v2009:141/issuetoc.

Nurchasanah, N., \& Habsari, Z. (2017). TEXT AS MEDIA, MATERIAL, AND LEARNING RESOURCES OF LITERATION TO DEVELOP A STUDENT CRITICAL THINKING ABILITY INSIDE THE DEVELOPMENT OF THE NATIONS. ISLLAC: Journal of Intensive Studies on Language, Literature, Art, and Culture, 1(1), 99-118.

Solomonides, I; Reid, A; \& Petocz, P. (2012). A relational model of student engagement. In I. Solomonides, A. Reid, \& P. Petocz (Eds.), Engaging with learning in higher education. Faringdon, UK: Libri Publishing

Thiagarajan, S; Semmel, D. S; and Semmel, M. I. (1974). Instructional Development for Training Teachers of Exceptional Children. Minnesota: University of Minnesota. 